\title{
SOME ROMAN COINS FROM REGENSBURG IN JOHANNESBURG
}

\author{
D B Saddington (University of the Witwatersrand)
}

Last year Mr. R. Faltermeier, a student in the Department of Classics at the University of the Witwatersrand, brought me nine Roman coins which he asked me to identify. He said that they had been brought to South Africa when his father had emigrated here from Regensburg in Germany.

Unfortunately he had no precise 'archaeological' information about the discovery of the coins. All that he knew was that they had been discovered in a field belonging to the family in the 1950s. (The field, which was subsequently sold, must have been in the grounds of the villa rustica or country estate of Neuprüll, now a suburb of Regensburg. In the 1970s an old-age home, the Johannesstift, was erected in the western part of the grounds of the villa.) However, the original owner of the coins, the student's grandfather, was also a collector. Accordingly, not all the coins need have come from Regensburg itself. ${ }^{1}$

The city of Regensburg (formerly Ratisbon) is an important site at the confluence of the Regen and the Danube. In Roman times the province to which it belonged was called Raetia (which corresponds to parts of S.E. Switzerland and W. Austria as well as Bavaria). At the end of the $1^{\text {st }}$ century A. D. the Romans built an earth and timber fort on the site. It was called Castra Regina (the Camp on the Regen). One of the early regiments stationed there was the Cohors III Britannorum Equitata, the Third Part-Mounted Unit of Britons. It was composed of auxiliaries, not legionaries, and had originally been raised in Britain: however, new levies for it would have been drafted locally rather than in Britain. (A cohort was roughly 500 strong.) A small civilian settlement soon grew up around the fort.

In the second half of the $2^{\text {nd }}$ century A.D. under Marcus Aurelius the Romans became involved in fighting the Marcomannic and other German tribes north of the Danube. (Scenes from the wars are sculpted onto the Column of Marcus Aurelius in the Piazza Colonna in Rome, where they can still be viewed.) During these Marcomannic Wars the fort at Castra Regina was destroyed. However, the site was re-occupied and a legionary fortress built on it. (The Porta Praetoria or North Gate of the fortress has survived to a height of 11 metres and can still be seen built into a later structure in the road 'Unter den Schwibbögen'.) The legion stationed in the fortress was the Legio III Italica, the Third Italian Legion. As before, a large civilian settlement soon grew up around it.

The coins range in date from the $1^{\text {st }}$ to the $6^{\text {th }}$ century A.D. In the earlier period the main Roman denomination was the golden aureus. It was the equivalent of 25 silver denarii. Originally, as its name, 'containing ten', indicates, the denarius equalled 10 asses but by this date it was equated to 16 of these bronze coins. (It is

I wish to thank Dr J van Heesch, Curator of the Coin Cabinet in the Royal Library of Belgium, Dr J Casey of London, Dr M Gschwind of Munich and Dr S Codreanu-Windauer of Regensburg for their kind assistance in identifying the coins and their location. 
extremely difficult to establish the value of ancient money: in the New Testament [Mt. 20,2] a denarius was a labourer's daily wage. Hence the bronze as was of comparatively little value.) The Romans were accustomed to calculating monetary sums in sestertii : a sestertius consisted of 4 asses (and was therefore $1 / 4$ of a denarius). By the later empire a different system of coinage was used, based on the gold solidus and the silver-plated follis.

1. The first coin, an as, was issued under the emperor Gaius, nicknamed Caligula (A.D. 38-41).
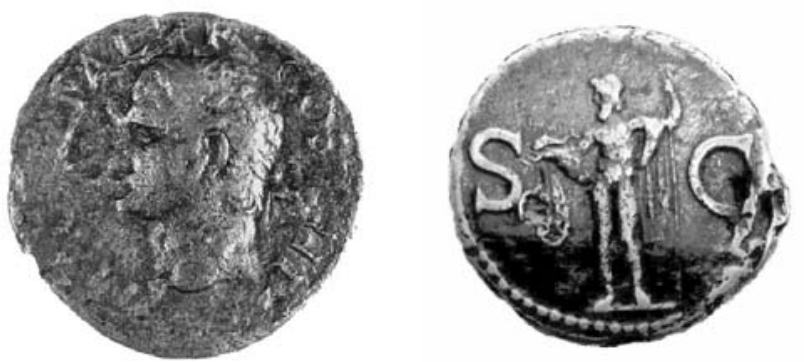

The obverse (or 'head' side) is a portrait of Gaius' maternal grandfather, M. Vipsanius Agrippa, who was a powerful general and admiral under the first emperor Augustus.

The legend (or writing on the coin) was $\mathrm{M} \cdot \mathrm{AGRIPPA} \cdot \mathrm{L} \cdot \mathrm{F} \cdot \mathrm{COS} \cdot$ III (but the first letters [M - AGRIPPA] are no longer legible) i.e. Marcus Agrippa, the son of Lucius, in his third consulship (the consul was the most prestigious political official in Rome after the emperor).

The reverse (or 'tail' side) depicts the sea god Neptune: it is a reference to Agrippa's naval victories. It is inscribed S · C, 'senatus consulto', 'by decree of the Senate' (the theoretical minting body).

The coin is discussed in RIC I ${ }^{2} 112$, no. 58.

2.

RIC II 282, no 540 pl. X 183 for the type, an as.
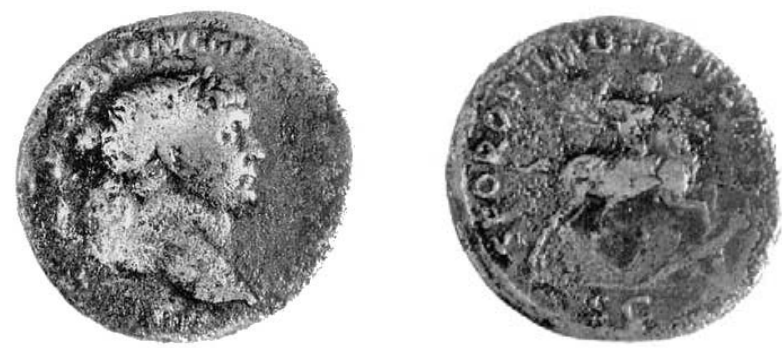
Obv. IMP $\cdot$ CAES $\cdot$ NERVAE TRAIANO AVG $\cdot$ GER $\cdot$ DAC $\cdot \mathrm{P} \cdot \mathrm{M} \cdot$ TR $\cdot$ POT $\cdot \operatorname{COS} \cdot \mathrm{V} \cdot \mathrm{P} \cdot \mathrm{P}$ (the first part of the legend is no longer legible). The legend encircles a portrait of the emperor's head. It lists his official titles - first his name (we use the element Trajan: he was emperor from A.D. 98-117), then that he had been acclaimed as GER(manicus) and DAC(icus), Victor over the Germans and the Dacians. He was COS V, i.e., had held his $5^{\text {th }}$ consulship, which occurred in 103.

Rev. SPQR $\cdot$ OPTIMO $\cdot$ PRINCIPI $\cdot \mathrm{S} \cdot \mathrm{C}$. S(enatus) P(opulus)Q(ue) R(omanus) OPTIMO PRINCIPI S(enatus) C(onsulto), 'The Senate and the Roman People to their Excellent Leader by decree of the Senate'.

The reverse shows the emperor thrusting his spear into a Dacian who has fallen beneath his horse. Trajan had conquered the Dacians and turned their territory into the province of Dacia (roughly modern Rumania) at the beginning of the $2^{\text {nd }}$ century A.D. Scenes from his Dacian Wars are portrayed on the Column of Trajan in the Foro di Traiano off the Via dei Fori Imperiali in Rome.

3.

RIC II, 295, nos. 713f.; an as.
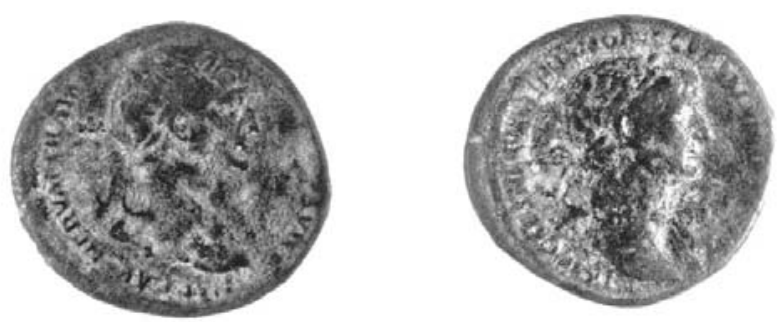

Obv. The head of Trajan with the legend IMP $\cdot$ CAES $\cdot$ NERVAE $\cdot$ TRAIA $[-] S$ $\cdot \mathrm{VI} \cdot \mathrm{P} \cdot \mathrm{P}$, laureated head right.

Rev. Laureated bust right, drapery on left shoulder.

IMP $\cdot$ CAES $\cdot$ NER $[-]$ RIANO $\cdot$ AVG $\cdot$ GER $\cdot$ DAC [

In effect, this is really a coin with two obverses, which was very rare in Roman coinage. 
4. Cf. RIC III p. 145, no. 967, a sestertius.
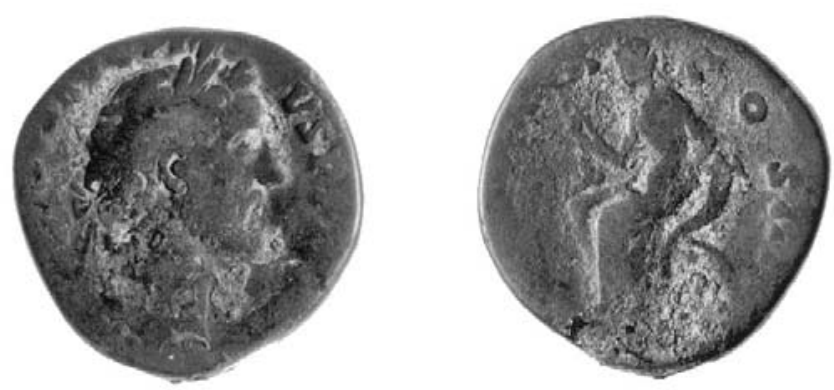

Obv. Head of Antoninus Pius. ANTONINVS $\cdot$ AVG $\cdot$ PIVS $\cdot$ P $\cdot$ P $\cdot$ IMP II

Rev. A female personification, probably of Justice, seated on a chair, with crossed cornucopiae ('horns of plenty') as arms; sceptre in right hand.

[TR - POT - X]X - COS III [after 141.] Antoninus Pius, 138-161, was the predecessor and father by adoption of Marcus Aurelius. He took a special interest in conditions in Italy.

5.

Cf. RIC III p. 163 no 1128 for the type, a sestertius.
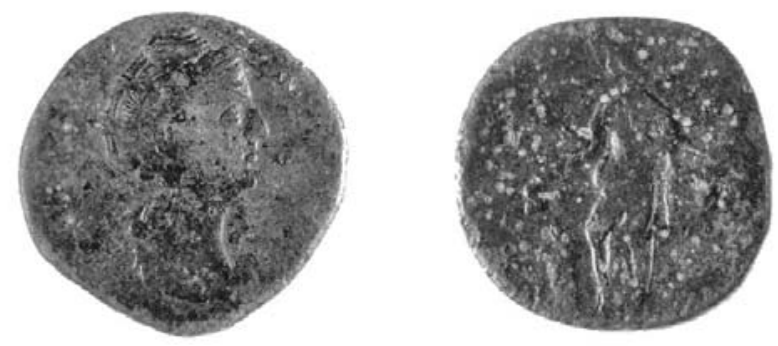

Obv. Head of Faustina I, Pius' deceased wife. DIVA FAVSTINA. ('Diva' means that she had been deified after her death).

Rev. S - C. A female figure, possibly the goddess Pietas or Religious Loyalty, before a lit altar, to the left.

Antoninus Pius erected a temple to his wife as DIVA: later, after his death, it was consecrated to him as well as DIVO ANTONINO. Its façade is still one of the most prominent ancient monuments in the Roman Forum: it survived by having been incorporated in the church of S. Lorenzo in Miranda. 
6. Commodus, struck under Marcus Aurelius. Sestertius, Rome, 179 A.D.
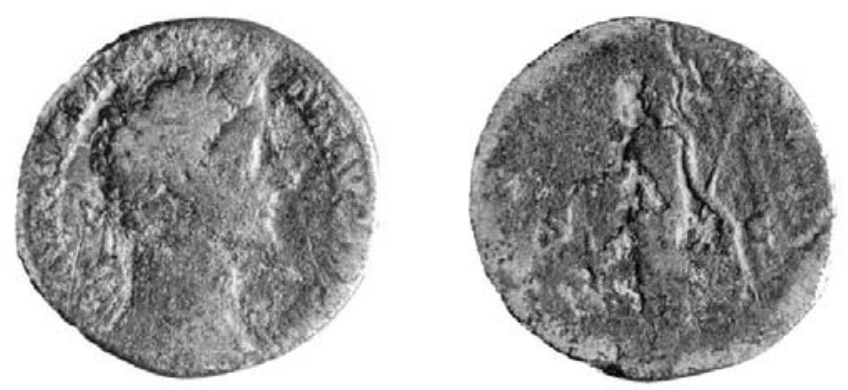

Obv. L] AVREL COMMO-DVS AVG TR P[iiii, laureated head right.

Rev. [imp ii cos ii pp], S/C, Minerva standing left, dropping incense on altar and resting left hand on shield; spear rests against her left arm.

BMC Roman Empire, IV p. 678 no 1699 and RIC (Marcus Aurelius), III, no 1599.

7. Cf. RIC VII p. 524, no 185, for the type, a nummus.
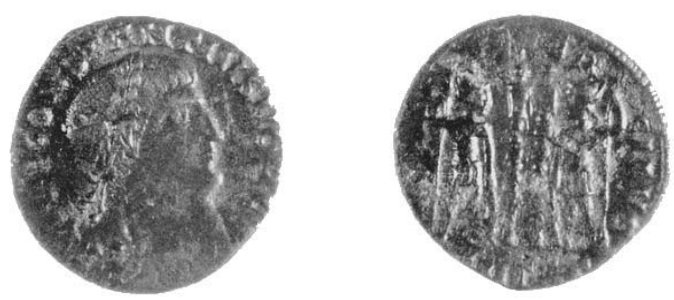

Obv. The head of Constantius II. FL $\cdot$ IVL $\cdot$ CONSTANTIVS $\cdot$ NOB $\cdot \mathrm{C}$ (= Nobilissimus Caesar)

'Flavius Julius Constantius (his full name), the most noble of Caesars.

Rev. Two soldiers holding two standards. GLORIA · EXERCITVS 'The glory of the army'.

Coins celebrating the excellence of the army were common under Constantine and his successors. The poor condition of this specimen makes it difficult to identify the mint and series to which it belonged. However in the exergue it may be possible to read ]MSTГ[, making it possible that the coin was struck at Thessalonica. 
8. Theodosius I. Aes-4, mint unidentified, 383-395 A.D.
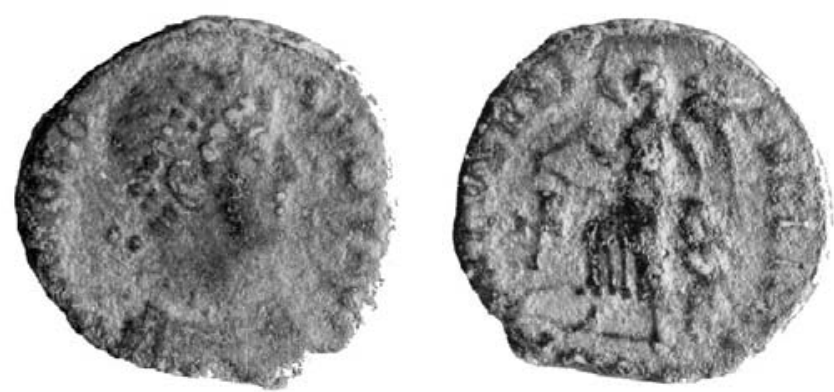

Obv. dn th[EODO-SIVS P F AVG, draped bust with pearl-diadem right.

Rev. SALVS REI-PVBLIC[AE, XP in field, Victory dragging captive left, mintmark not visible.

RIC IX p. 106 no 58b (= this type from Aquileia, but the coin was minted also in Rome and several Eastern mints). This coin has a 'sandy'-patina and looks very much like the coins coming from the Levant, North Africa or Spain.

9. Similar to Sear, pp. 55f., follis.
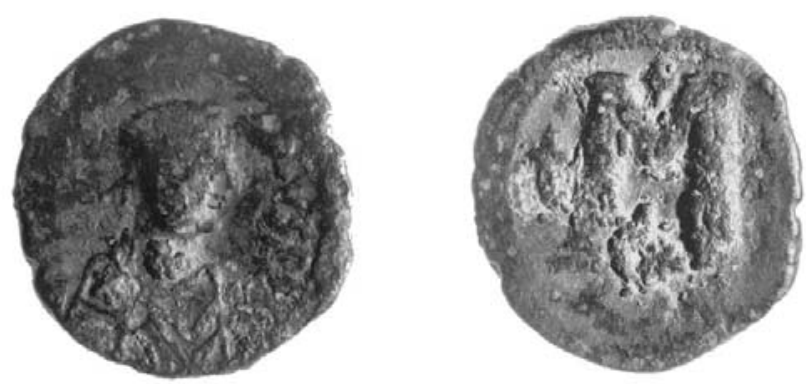

Obv. Bust of an emperor. Legend almost entirely eroded: only [ - - - ]VS $\cdot$ P $\cdot$ P survives.

Rev. A capital ' $M$ ' surrounded by stars and crosses. Legend no longer legible. This is strictly not a Roman, but a Byzantine, coin. It was probably issued in the sixth century A.D., possibly by Justin I or Justinian I (reading [IVSTIN] or [IVSTINIAN] in the lacuna before ]VS). ' $M$ ' is the Greek numeral 40; the coin was worth 40 nummi.

\section{BIBLIOGRAPHY}

Dietz, K et al. 1979. Regensburg zur Römerzeit. Regensburg: F. Pustet.

Jutting, I 1997. Die römische Villa Rustica auf dem Gelände des Bezirksklinikums Regensburg. In 1000 Jahre Kultur in Karthaus-Prüll. Regensburg: F. Pustet. RIC 1923-1981: The Roman Imperial Coinage. Edited by H Mattingly et al. $2^{\text {nd }}$ ed 1984 C H V Sutherland (ed.). London: Spink.

Sear, D 1974. Byzantine Coins and Their Values. London: Seaby. 